\title{
APLIKASI FORUM PAJAK MENGGUNAKAN FRAMEWORK BOOTSTRAP
}

\author{
Try Viananda Nova Megariani \\ Fakultas Teknologi Informasi \\ Universitas Islam Kalimantan Muhammad Arsyad Al Banjari Banjarmasin \\ novamegariani@gmail.com
}

\begin{abstract}
ABSTRAK
Pajak memiliki ketentuan yang perlu diketahui dan ditaati yaitu Ketentuan Umum dan Tata Cara Perpajakan atau yang biasa disingkat dengan KUP. Ada juga mengenai pengenaan pajak penghasilan (PPH) atau pajak yang dikenakan pada penghasilan perorangan, perusahaan atau badan hukum lainnya. Pajak penghasilan bisa diberlakukan progresif, proporsional atau regresif. Dan salah satu lainnya ialah Pajak Pertambahan Nilai (PPN) yang merupakan pajak yang dikenakan atas setiap pertambahan nilai dari barang atau jasa dalam peredarannya dari produsen ke konsumen. PPN termasuk jenis pajak tidak langsung, maksudnya pajak tersebut disetor oleh pihak lain (pedagang) yang bukan penanggung pajak atau dengan kata lain, penanggung pajak (konsumen akhir) tidak menyetorkan langsung pajak yang ia tanggung. Dan hal-hal seperti ini, merupakan bahan perbincangan untuk pajak yang sering kali perlu didiskusikan antar unit dengan pusat atau korporat. Sehingga diperlukan sekali komunikasi yang lebih efektif, cepat, rapih dan terarah untuk bisa dibahas dan dibaca kembali dikemudian hari oleh seluruh pajak setiap unit dan pusat.
\end{abstract}

Kata Kunci : Pajak 


\section{PENDAHULUAN}

PT. Pertamina Bina Medika atau PERTAMEDIKA adalah salah satu anak perusahaan Pertamina berupa Korporat yang membidangi Layanan Kesehatan di lingkungan Pertamina dan memiliki unit usaha yang terdiri dari 10 buah rumah sakit yang tersebar di seluruh Indonesia. Setiap unit memiliki bagian keuangan yang mengatur dan mengontrol seluruh layanan keuangan yang berhubungan dengan unit usaha dan salah satu layananya yaitu pajak. Pajak adalah kontribusi wajib kepada negara yang terutang oleh orang pribadi atau badan yang bersifat memaksa berdasarkan Undang-undang, dengan tidak mendapatkan imbalan secara langsung dan digunakan untuk keperluan negara bagi besarnya kemakmuran rakyat (Dasar Hukum : Pasal 1 UU No 28 Tahun 2007).

Pajak memiliki ketentuan yang perlu diketahui dan ditaati yaitu Ketentuan Umum dan Tata Cara Perpajakan atau yang biasa disingkat dengan KUP. Ada juga mengenai pengenaan pajak penghasilan (PPH) atau pajak yang dikenakan pada penghasilan perorangan, perusahaan atau badan hukum lainnya. Pajak penghasilan bisa diberlakukan progresif, proporsional atau regresif. Dan salah satu lainnya ialah Pajak Pertambahan Nilai (PPN) yang merupakan pajak yang dikenakan atas setiap pertambahan nilai dari barang atau jasa dalam peredarannya dari produsen ke konsumen. PPN termasuk jenis pajak tidak langsung, maksudnya pajak tersebut disetor oleh pihak lain (pedagang) yang bukan penanggung pajak atau dengan kata lain, penanggung pajak (konsumen akhir) tidak menyetorkan langsung pajak yang ia tanggung. Dan hal-hal seperti ini, merupakan bahan perbincangan untuk pajak yang sering kali perlu didiskusikan antar unit dengan pusat atau korporat. Sehingga diperlukan sekali komunikasi yang lebih efektif, cepat, rapih dan terarah untuk bisa dibahas dan dibaca kembali dikemudian hari oleh seluruh pajak setiap unit dan pusat. Forum menurut Bahasa adalah lembaga atau badan tempat membicarakan kepentingan bersama dan sering dimanfaatkan untuk diskusi ilmiah. Sedangkan komunikasi menurut bahasa adalah pengiriman dan penerimaan pesan atau berita antara dua orang atau lebih sehingga pesan yg dimaksud dapat dipahami. Forum merupakan tempat berkumpulnya suatu komunitas secara online dan biasanya membahas suatu topik atau masalah yang berkaitan dengan forum tersebut. Untuk membuat web forum, kini telah banyak tersedia website yang memberikan layanan untuk membuat forum dengan mudah seperti halnya membuat blog. Bootstrap adalah sebuah framework yang dapat menyelesaikan permasalahan dalam mendesain web. Slogan dari framework ini adalah "Sleek, intuitive, and powerful front-end framework for faster and easier web development", yang berarti kita dapat mendesain sebuah website dengan lebih rapi, cepat dan mudah. Selain itu, Bootstrap juga responsif terhadap banyak platform, artinya tampilan halaman website yang menggunakan Bootstrap ini akan tampak tetap rapi, baik versi mobile maupun desktop. Twitter Bootstrap dibangun dengan teknologi HTML dan CSS yang dapat membuat layout halaman website, tabel, tombol, 
form, navigasi, dan komponen lainnya dalam sebuah website hanya dengan memanggil fungsi CSS (class) dalam berkas HTML yang telah didefinisikan (Widyantoro Wahyu, Buku Panduan Bootstrap, 2014). Selain itu juga terdapat komponen-komponen lainnya yang dibangun menggunakan JavaScript dan PHP. PHP: Hypertext Preprocessor adalah bahasa skrip yang dapat ditanamkan atau disisipkan ke dalam HTML. PHP banyak dipakai untuk memrogram situs web dinamis. PHP dapat digunakan untuk membangun sebuah CMS. Dalam sisi pengembangan lebih mudah, karena banyaknya milis - milis dan para pengembang yang siap membantu dalam pengembangan. Dalam sisi pemahamanan, PHP adalah bahasa scripting yang paling mudah karena memiliki referensi yang banyak. PHP adalah bahasa open source yang dapat digunakan di berbagai mesin (Linux, Unix, Macintosh, Windows) dan dapat dijalankan secara runtime melalui konsol serta juga dapat menjalankan perintah-perintah sistem. Untuk itu, penulis merancang dan merealisasikan aplikasi dengan menggunakan framework Bootstrap sesuai dengan requirement dikarenakan web yang sedang dikembangkan oleh Pertamedika menggunakan Twitter Bootstrap. Bootstrap adalah sebuah framework yang dapat menyelesaikan permasalahan dalam mendesain web. Slogan dari framework ini adalah "Sleek, intuitive, and powerful frontend framework for faster and easier web development", yang berarti kita dapat mendesain sebuah website dengan lebih rapi, cepat dan mudah. Selain itu, Bootstrap juga responsif terhadap banyak platform, artinya tampilan halaman website yang menggunakan Bootstrap ini akan tampak tetap rapi, baik versi mobile maupun desktop. Saat ini penggunaan Bootstrap sudah meluas di kalangan disainer front- end web, perkembangannya pun masih terus berlangsung hingga sekarang. Penggunaannya tidak begitu rumit. Karena hanya tinggal memanggil CSS dan JS yang tersedia lalu menuliskan class-class nya pada script. Bootstrap memiliki 12- column responsive grid, macam-macam komponen, JavaScript plugins, typography, form controls, dan juga sebuah web- based Customizer untuk membuat Bootstrap sendiri (Widyantoro Wahyu, Buku Panduan Bootstrap, 2014). Dengan hak akses user, admin, dan superadmin maka komunikasi yang diharapkan adalah komunikasi yang mampu menyimpan percakapannya untuk dapat dibaca kembali sebagai informasi untuk setiap unit perusahaan dalam bentuk forum, dengan tiga hak akses yaitu user, admin dan superadmin. Dimana setiap pesan terkirim, akan melalui dua kali tahap yaitu admin dan superadmin untuk bisa tampil ke tabel percakapan. Setiap chat atau messages yang masuk dari user akan langsung masuk ke tabel pada web admin dan superadmin dengan hak akses pada admin yaitu untuk menjawab dan menghapus pertanyaan pada pesan yang diterima. Dan pada superadmin tabel yang tampil pada web adalah tabel yang berisi pesan dari user baik dengan pesan yang sudah dijawab oleh admin ataupun tidak. Dan dengan hak akses khusus yang dimiliki superadmin yaitu submit dimana pesan tersebut akan terkirim kepada user untuk tampil 
pada tabel user. Untuk itu penulis menerapkan forum pada web dengan tiga hak akses dan menggunakan framework bootstrap

\section{TUJUAN DAN KEGUNAAN}

Praktik kerja lapangan ini bertujuan untuk : Mempelajari dan menganalisa sistem informasi dan komunikasi divisi Pajak di PT. Pertamina Bina Medika. Merancang dan mengimplementasikan Aplikasi Forum Komunikasi untuk divisi Pajak di PT. Pertamina Bina Medika Menerapkan dan mempraktikan ilmu yang didapat selama kuliah. Adapun Praktik kerja lapangan ini berguna sebagai berikut : Mendapatkan konsep pemikiran yang terpadu yang mampu menerapkan teori dan praktik dalam menganalisa suatu sistem kerja. Mendapat pengetahuan, keterampilan dan pengalaman terkait proses dan cara-cara pembuatan sebuah Sistem Informasi data suatu perusahaan di PT. Pertamina Bina Medika.

1. Memahami pekerjaan seorang IT yang bergerak di bidang jasa yang harus mengerti akan keinginan seorang client.

2. Mampu menerapkan disiplin ilmu yang telah dipelajari dan pengetahuan yang telah diterima selama kuliah, ke dalam praktik kerja langsung di lapangan.

3. Dengan adanya aplikasi ini, memudahkan komunikasi antar pajak seluruh unit dengan pusat atau korporat.

4. Mengefektifkan komunikasi yang terarah, efisien dan rapih pada forum pajak.

\section{METODE PENELITIAN}

Unit Kerja Lapangan

Penulis melakukan Penelitian di PT. Pertamina Bina Medika. Penulis ditempatkan di bagian informasi teknologi dan menerima dua buah projek dari Pertamedika. Projek pertama penulis terima dari divisit SDM untuk membuat aplikasi calon pegawai baru di Pertamedika. Dan projek kedua penulis terima dari divisit Pajak yaitu membuat aplikasi forum komunikasi yang akan diimplementasikan oleh seluruh unit dengan pusat/korporat.

Struktur Organisasi PT. Pertamedika

Struktur organisasi merupakan pembagian wewenang dan tugas dalam menjalankan setiap amanat yang diberikan kepada pekerja dari perusahaan tersebut dalam pencapaian visi dan misi yang telah ditetapkan oleh perusahaan. Lebih jelasnya dapat dilihat struktur organisasi PT. Pertamina Bina Medika pada gambar 3.1 Struktur Organisasi Pertamedika. Bagan yang berwarna biru, merupakan divisi dimana penulis ditempatkan yaitu Teknologi Informatika. Dibawah pimpinan manajer TI Bapak Eko Sulistyo, divisi TI Pertamedika berjalan sesuai dengan fungsinya. Dan berikut adalah tugas atau kegiatan utama Manajer Teknologi

Informatika sesuai dengan yang telah ditetapkan,yaitu;

1. Memberikan laporan rutin

$\begin{array}{lcc}\text { kepada } & \text { Direktur } & \text { Utama } \\ \text { mengenai } & \text { kegiatan } & \text { sistem } \\ \text { teknologi } & \text { informasi } & \text { PT. } \\ \text { Pertamina Bina Medika } & \end{array}$

2. Memonitor kegiatan 
administrasi Teknologi Informasi PT. Pertamina Bina Medika

3. Berkoordinasi dnegan bagan lain yang terkait dengan teknologi informasi

4. Melaksanakan tugas - tugas lain yang diperintahkan oleh atasan. Dengan bimbingan langsung dari Bapak Eko Sulistyo selaku pembimbing instansi, penulis menerima ilmu dan arahan untuk setiap tugas yang penulis terima. Penulis jadi mengerti dan lebih memahami fungsi dari kinerja pekerja TI dalam praktik di lapangan.

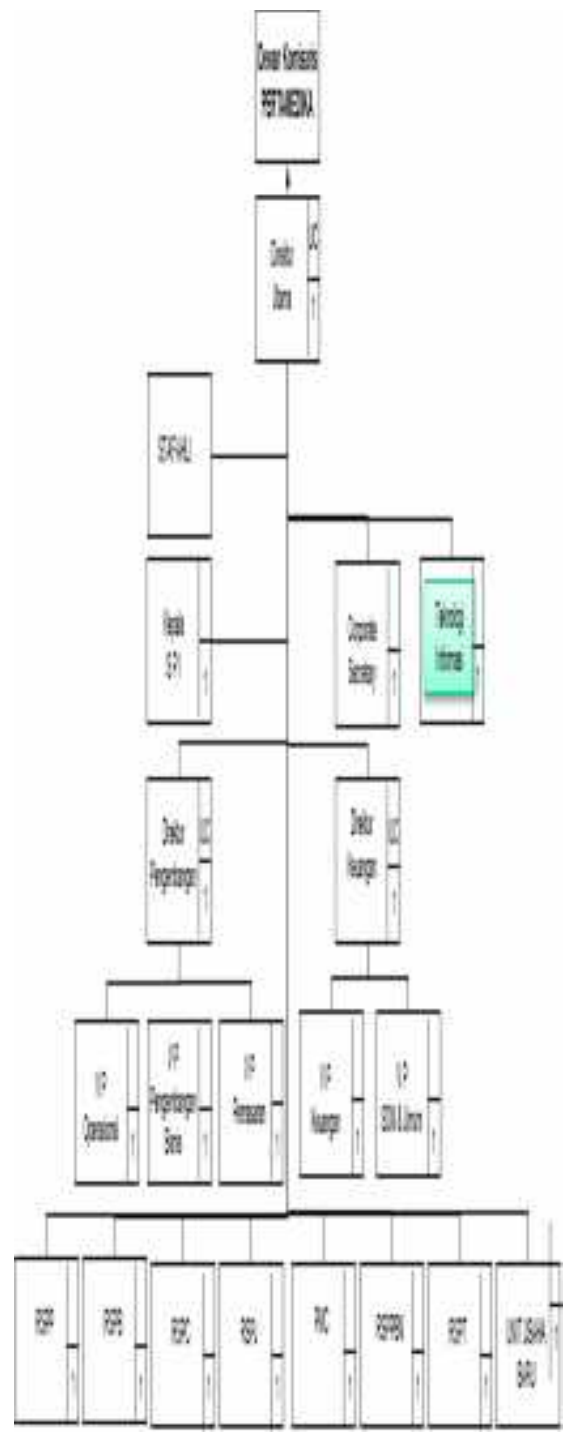

Gambar 3.1 Struktur Organisasi Pertamedika

\section{HASIL DAN PEMBAHASAN}

User Requirement

Permintaan user atau User Requirement merupakan permintaan awal dari user mengenai projek forum aplikasi dan menjadi data awal yang diterima sebagai kerangka untuk aplikasi. Berikut adalah beberapa 
poin untuk permintaan forum yang diinginkan user;

1) Terdapat tiga hak akses yaitu Superadmin, Admin dan User

2) Setiap pesan yang terkirim akan diterima admin dan superadmin

3) Pesan dapat dijawab oleh admin namun tidak akan langsung terkirim ke halaman percakapan tapi terkirim ke Superadmin

4) Pesan yang akan tampil di halaman percakapan User harus dengan konfirmasi Superadmin

5) Superadmin memberi jawaban atau menambahkan jawaban admin lalu submit ke User

6) Admin dapat melihat pesan yang tampil dihalaman User

7) Pesan dari User, Admin dan Superadmin dapat mem-paste gambar (.jpeg, .jpg, .png )

8) Pesan dapat dihapus oleh admin dan superadmin apabila dianggap tidak sesuai tema dan tidak perlu di pasang di halaman percakapan

9) Pesan yang sudah dikonfirmasi dan tampil di halaman user dapat juga dilihat oleh admin dan superadmin

10)Pesan yang sudah dikonfirmasi dan tampil di halaman user dapat dihapus oleh superadmin

11)User, admin dan superadmin dapat meng-upload file atau lampiran

\section{BISNIS PROSES}

Perancangan Konsep

Sesuai dengan ketentuan yang disepakati dan disetujui dari hasil pertemuan dengan divisit Pajak atas permintaan aplikasi forum komunikasi. Dimana dalam forum tersebut setiap user yang telah mengirim pesan akan menerima konfirmasi bahwa pesannya telah diterima admin. Dan pesan tersebut tidak akan langsung tampil ditabel halaman user seperti forum pada umunya. Melainkan pesan tersebut diterima terlebih dahulu di halaman admin dan superadmin. Di halaman admin akan tampil pesan yang dikirim oleh user dan admin dapat langsung menjawab atau menghapus pesan - pesan tersebut. Dan setiap pesan yang telah dijawab akan terupdate di halaman superadmin. Admin juga dapat melihat halaman yang akan tampil di user.

Untuk superadmin, akan tampil halaman berisi tabel atas pesan dari user baik yang telah dijawab oleh admin maupun yang belum. Dan pada tabel tersebut superadmin dapat menjawab, menghapus dan mengirim langsung pesan tersebut agar tampil di halaman user tanpa perlu di edit atau ditambahkan. Superadmin juga memiliki akses mengontrol halaman yang telah tampil pada user untuk melihat dan menghapus data pesan yang sudah lama atau sudah diperbaharui dan berulang.

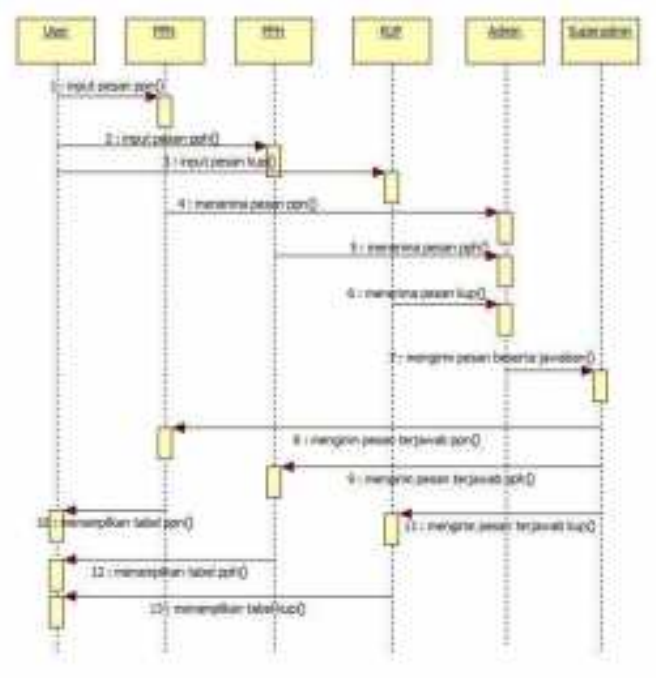


Gambar 3.2 Sequence Diagram

Perancangan Proses

Dalam perancangan Aplikasi, dibutuhkan sebuah model basis data untuk menyimpan data yang dibutuhkan.

\section{DFD}

Data flow diagram ini dibuat sebagai rancangan dari aliran data yang terjadi pada aplikasi. Dan terdiri dari diagram korteks dan diagram penurunannya.

\section{Diagram Konteks}

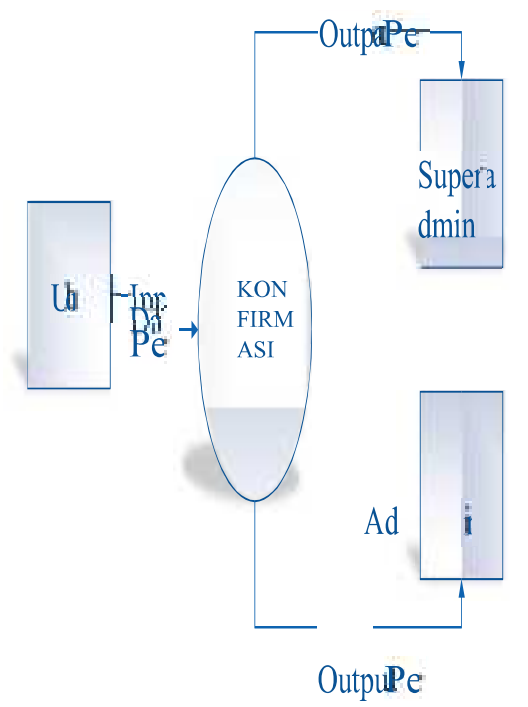

Diagram 3.3 Diagram

Konteks

Penjelasan untuk diagram diatas yaitu user membuat suatu pesan kemudian menginput pesan tersebut dan kemudian menerima konfirmasi bahwa pesan tersebut telah diterima oleh admin. Kemudian dari konfirmasi tersebut maka otomatis juga menghasilkan ouput pada admin dan superadmin yaitu berupa data pesanang masuk kedalam tabel masing - masing.
D Int

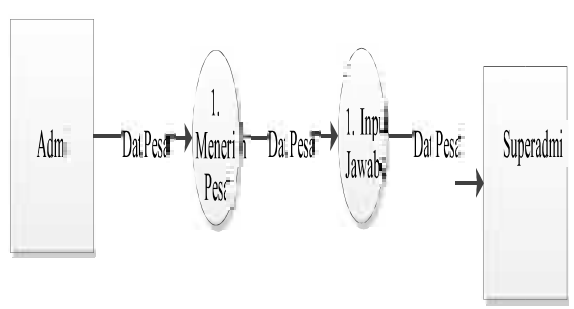

Diagram 3.4 DFD Level-1

Penjelasan selanjutnya, yaitu pada diagram 3.4 DFD level-1. Disini digambarkan bahwa Admin memiliki proses awal yaitu menerima data pesan. Kemudian Admin melakukan proses selanjutnya yaitu, input atau memasukan data pesan dengan jawabannya kepada superadmin.

Flowchart

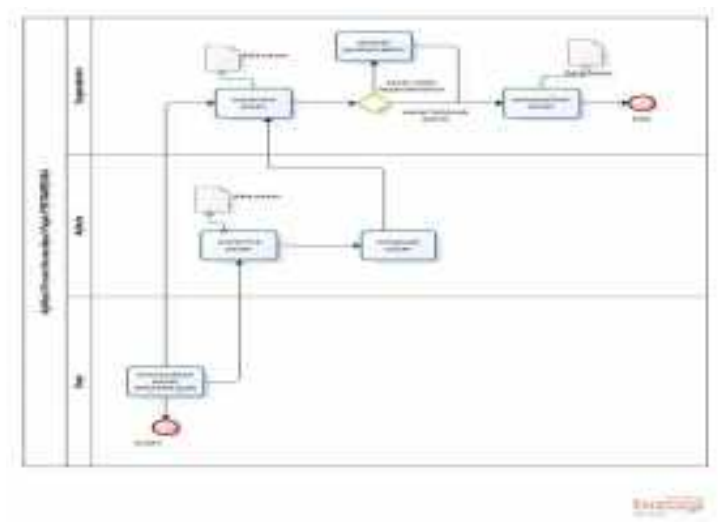

Gambar 3.10 Flowchart Forum

Realisasi Aplikasi

Dalam perancangan aplikasi, realisasi aplikasi merupakan tahapan akhir yang berupa gambaran atau hasil dari implementasi untuk perancangan aplikasi. Dan berikut adalah hasil implementasi aplikasi berupa tampilan forum.

Tampilan Forum

Berikut adalah gambaran dari implementasi aplikasi saat dijalankan; 
1) Halaman utama Pajak PERTAMEDIKA

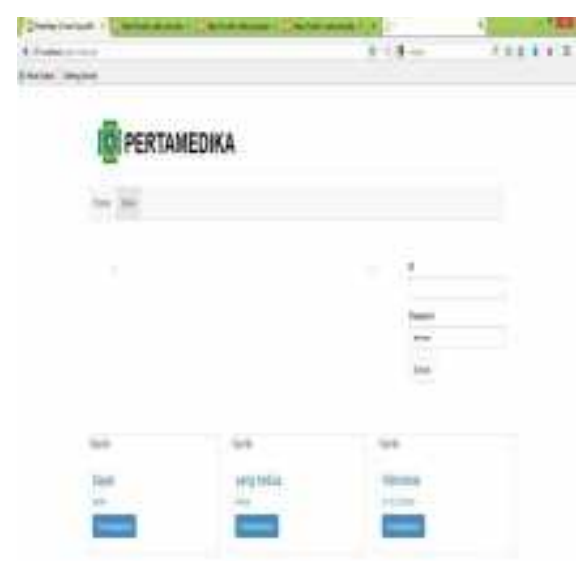

Gambar 3.12 Pajak

Halaman pertama User setelah login

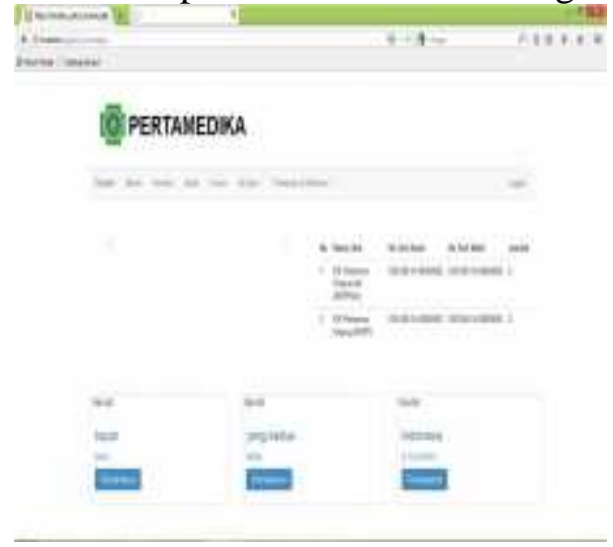

Gambar 3.14 Home User

Halaman Forum untuk User (PPH)
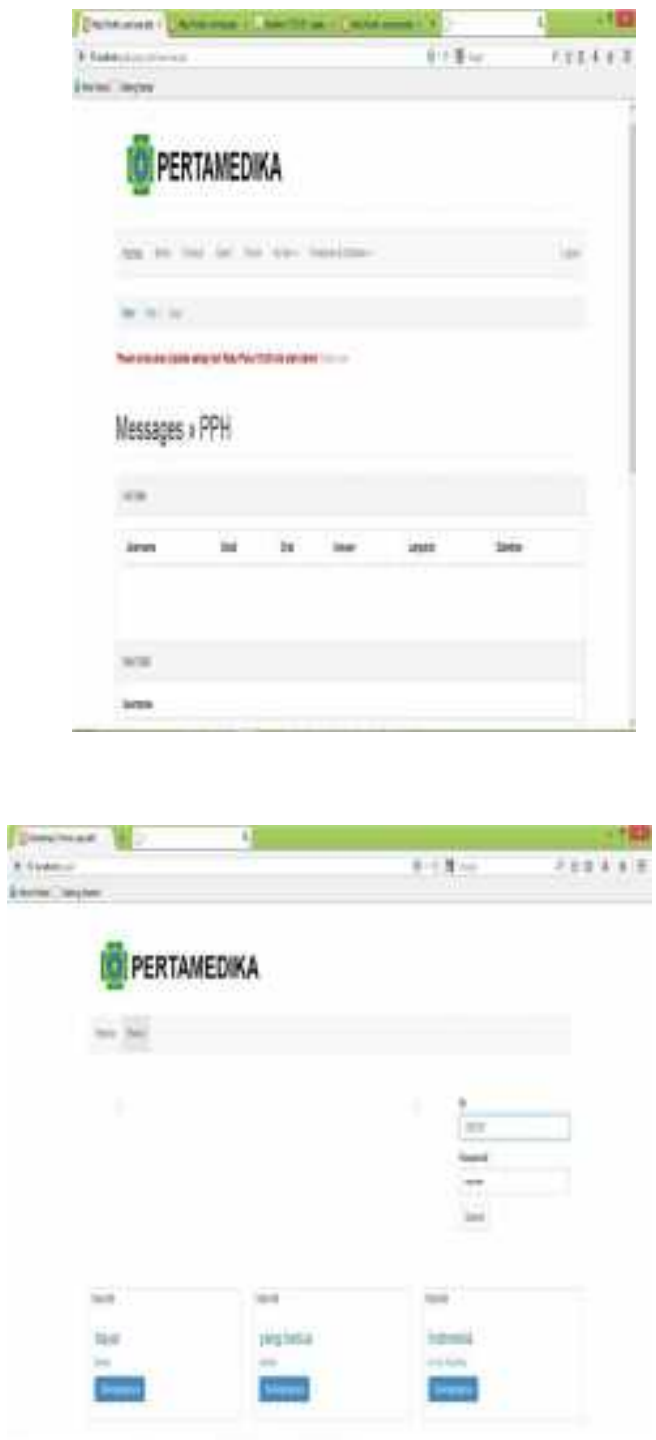

Gambar 3.15 Forum User Pph

Forum Forum untuk User (PPN)

Jurnal Ilmiah Fakultas Teknik "Technologia" 


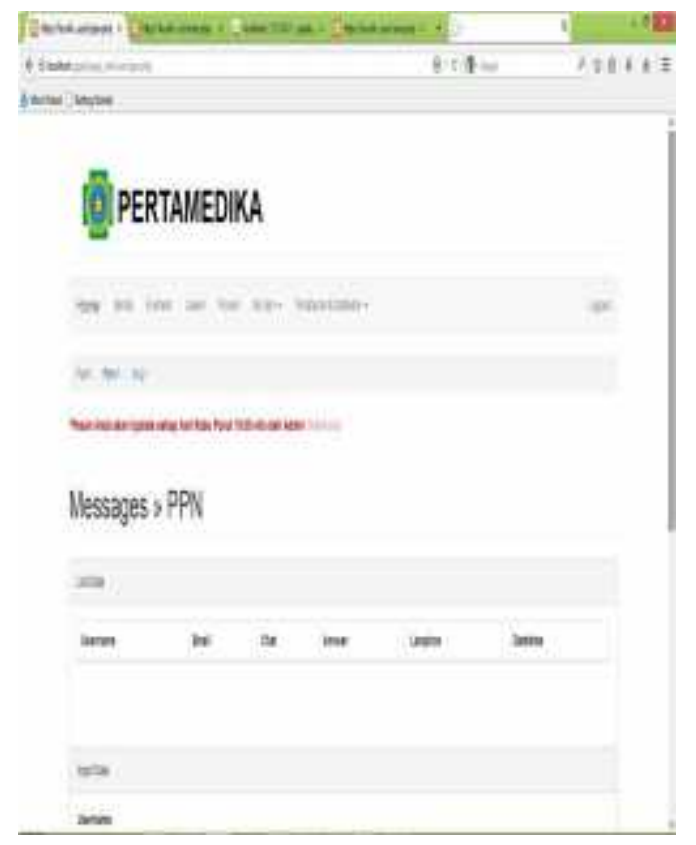

Gambar 3.16 Forum User Ppn Forum Forum untuk User (KUP)

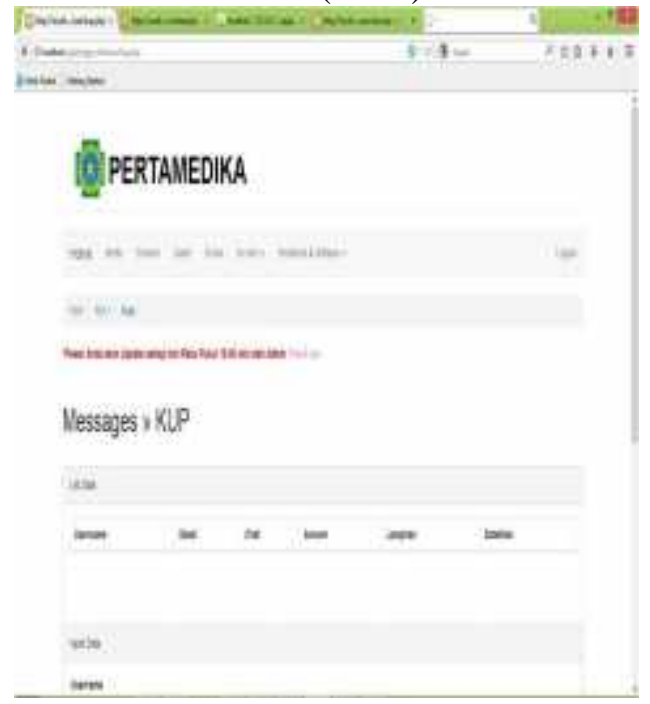

Gambar 3.17 Forum User Kup

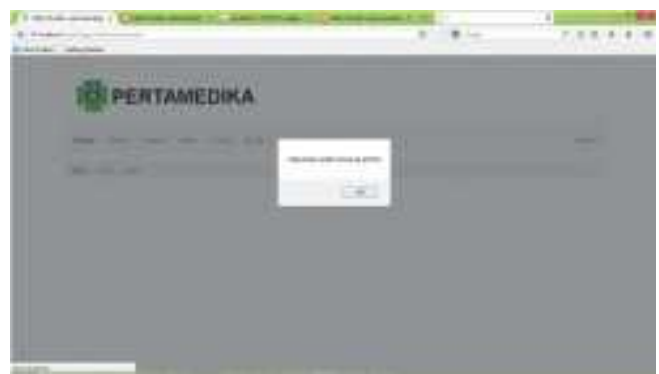

3) Login Admin

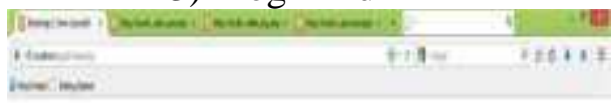

\section{6] PERTANEDIKA}
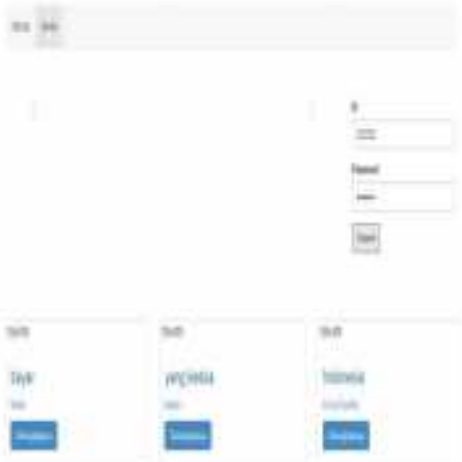

Gambar 3.20 Login Admin Halaman pertama Admin setelah login 

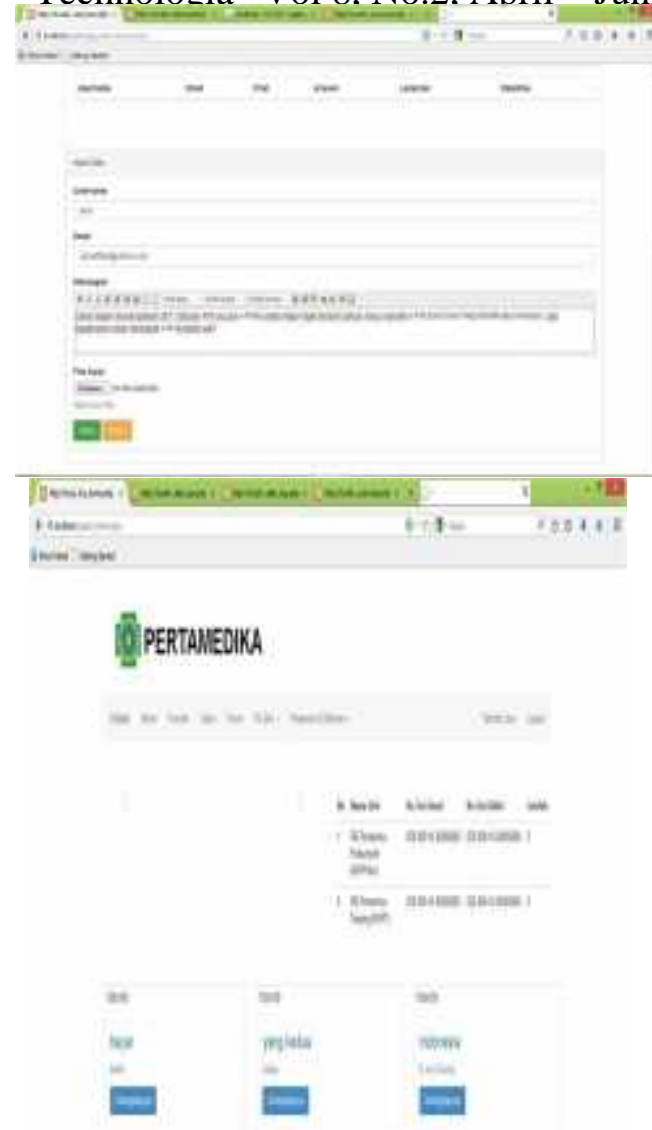

Gambar 3.21 Home Admin

Halaman pertama Forum Admin (PPH)

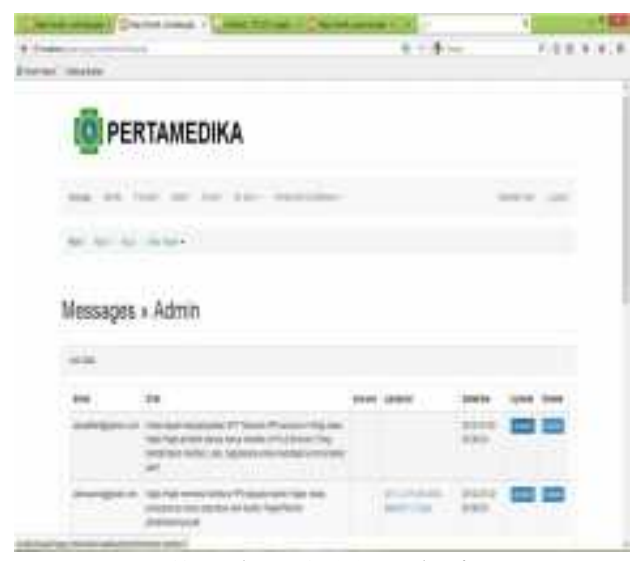

Gambar 3.22 Admin

Pesan untuk Admin (setelah mengklik button Answer dari table pesan)

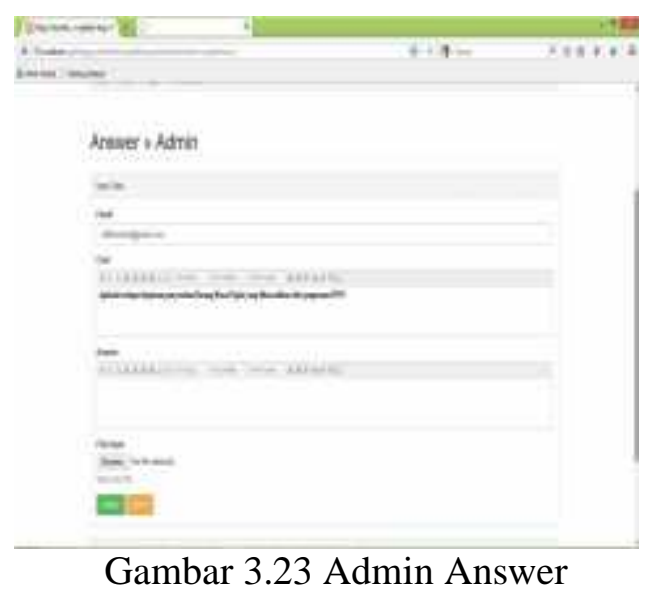

Notifikasi Admin (“Success")

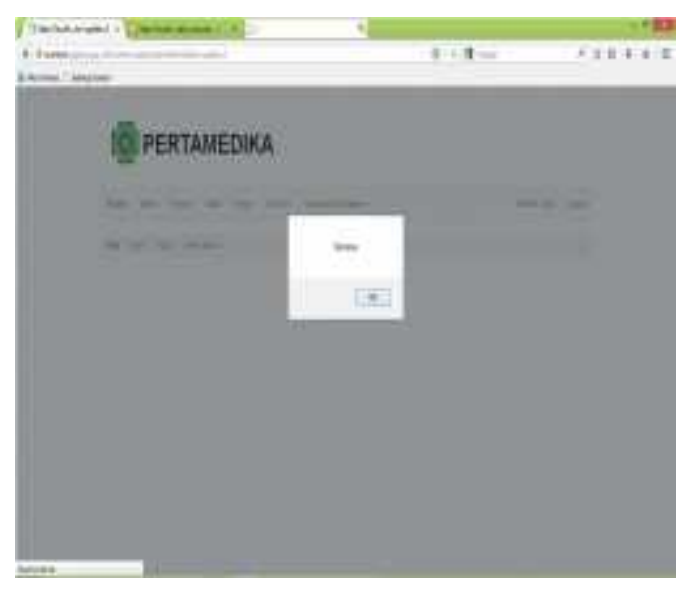

Gambar 3.24 Admin Notifikasi

\section{DAFTAR PUSTAKA}

Halim, Abdul.2014. Perpajakan : Konsep, Aplikasi, Contoh, dan Studi Kasus. Jakarta : Salemba Empat.

Resmi, Siti.2014. Perpajakan : Teori dan Kasus. Jakarta : Salemba Empat.

Suandy, Erly.2014.Hukum Pajak. Jakarta : Salemba Empat.

Muljono, Djoko.2009.Pengantar PPh dan PPh Pasal 21 Lengkap dengan

Jurnal Ilmiah Fakultas Teknik "Technologia" 
Undang-Undang. Yogyakarta : CV.ANDI OFFSET

Parinduri, Ikhsan Amri. 2016. Pajak

Penghasilan Pasal 21. Medan (Modul Brevet

Tax Centre Universitas Sumatera Utara)

Dalimunthe, Esmil Shaleh.2016. PPh

Orang Pribadi.Medan (Modul

Brevet Tax

Centre Universitas Sumatera Utara)

Peraturan Perundang-Undangan

Undang-Undang Nomor 36 Tahun 2008, tentang Perubahan Keempat atas

Undang-Undang Nomor 7 Tahun 1983

Tentang Pajak Penghasilan

Undang-Undang Nomor 16 Tahun 2009, tentang perubahan keempat UndangUndang

Nomor 6 Thun 1983 tentang Ketentuan Umum dan Tata Cara

Perpajakan

Peraturan Menteri Keuangan Nomor 101/PMK.010/2016

https://id.wikipedia.org/wiki/Penghasilan _tidak_kena_pajak

diakses tanggal 8-04-2017 pada pukul 11.00

http://www.jdih.kemenkeu.go.id/fullText/ 2016/101 PMK.010 2016Per.pdf

diakses tanggal 8-04-2017 pada pukul 11.00

http://www.kemenkeu.go.id/Berita/mulai -januari-2016-ptkp-naik-jadi-rp54jutatahun

diakses tanggal 9-04-2017 pada pukul 17.30

http://www.kemenkeu.go.id/sites/default/ files/SP_31.pdf

diakses tanggal 9-04-2017 pada pukul 18.00

diakses tanggal 9-04-2017 pada pukul 21.00

http://www.pajak.go.id/sites/default/files/ UU-PPh-001-13-

UU\%20PPh\%202013-
00\%20Mobile.pdf

diakses tgl 8-04-2017 jam 12.15

m.kompasiana.com diakses pada 8-042016 pukul 22.00

m.detik.com diakses pada 8-04-2017 pukul23.00

http://repository.ut.ac.id/4532/1/PAJA33 39-M1.pdf

diakses tanggal 9-04-2017 pada pukul 18.00

http://www.kemenkeu.go.id/apbn2017

diakses tanggal 29-04-2017 pukul 20.00

http://www.anggaran.depkeu.go.id/conte nt/publikasi/2016\%20BIB\%202017. pdf

diakses tanggal 29-04-2017 pukul 20.00 http://www.pajak.go.id/content/article/pe ran-pajak-untuk-mencapaitargetpertumbuhan-ekonomi-2017 diakses tanggal 29-04-2017 pukul 20.00 http://ketentuan.pajak.go.id/aturan/asli/P ER-20.PJ.2013.pdf 